\title{
Study on Basic Theory and Accounting of Off-balance Sheet Activities in Commercial Bank
}

\author{
Xin Cheng ${ }^{1, a}$, Yinxing $\mathrm{Li}^{2, \mathrm{~b}, *}$ \\ ${ }^{1}$ School of Economic Management, Beihua University, 132013, Jilin City, China \\ axin-cheng007@126.com, ${ }^{b}$ nyjjgl@126.com \\ ${ }^{*}$ Corresponding author
}

Keywords: Commercial bank, exchange rate, accounting internal control, OBSA.

\begin{abstract}
OBSA(the Off-balance Sheet Activities) of the commercial banks of china is still at a low level. with the market pressure and exchange rate challenge how to bring up by deepening of financial restructuring, interest rate, securitization, and introduction of foreign banks after china's entry into WTO should be made in order to promote our bank's OBSA. In this paper, the methods of concluding, demonstrating, analyzing and comparing to discuss OBSA in terms of background, reasons, influence, risks and its control in order to internal control system are put forward based on the situation of our banks' OBSA.
\end{abstract}

\section{Introduction}

The traditional two basic businesses of commercial banks are asset business and liability business, both of which are embodied in the balance sheet of commercial banks. The rapid development in recent decades is the third category of business a balance sheet outside the business, that is, off-balance sheet business. According to the Basel Accord, the concept of Off-balance Sheet Activities (OBSA) can be divided into two categories: narrow sense and broad sense.

Contingent Claims refers to transactions conducted by commercial banks that are not included in the balance sheet in accordance with traditional accounting standards. They do not affect the total amount of bank assets and liabilities, but can change current profit and loss and working capital, Asset return rate of the business activities. Banks in the handling of these operations, although no actual cash receipts and payments, nor advance any funds or only a small amount of advance capital, but with the close relationship with the asset and liability business in the future may at any time due to a contract in a condition And therefore need to be registered outside the table in order to reflect, accounting, control and management. Since these off-balance-sheet activities are converted into on-balance sheet business when the risk becomes a reality, the narrow-form off-balance sheet business is also known as contingent asset or contingent liability. Often referred to the off-balance sheet business refers to the narrow form of business.

The so-called generalized off-balance-sheet business refers to all operations not included in the balance sheet relative to the balance sheet business. Such operations are neither reflected in the asset side nor reflected in the liability side. In addition to including the above-mentioned narrow-minded business outside the table, but also including settlement, agency, consulting and other risky business activities.

The Basel Committee divides off-balance sheet operations into two main categories: one is contingent claims/obligations, i.e., narrow-form off-balance sheet operations, which include: (1) loan commitments ( 2) Warranty (3) Derivatives, such as swaps, futures, options, forward contracts, upper and lower interest rates, etc. (4) Investment banking business including securities agency,

Securities sales, gold trading. Second, financial services, including: (1) trust and advisory services (2) payment and settlement (3) agent services (4) loan-related services, such as loan organizations, loan approval, syndicated loans Agents, etc. (5) import and export services, such as agency services, trade declarations, insurance agents, and other services. 
This classification divides off-balance-sheet operations into two basic categories: risky off-balance-sheet operations and risk-free off-balance sheet operations. The financial services business is risk-free off-balance-sheet business, the bank only provides financial services without taking risks. In the narrow sense, the off-balance sheet business is completely different. Although the business carried out by the bank is not reflected in the balance sheet, it is a potential asset or liability. Under certain conditions, it will be converted to the in-table business. To gain risk.

\section{Risk Control and Information Disclosure of Off - balance Sheet Business of Commercial Banks}

From the current international commercial banks, the development of off-balance-sheet business, the use of off-balance sheet business to diversify and transfer risk more widely. Off-balance sheet business provides effective help for capital to avoid risk, but it can not avoid all risks. Owing to its uncertainty, off-balance-sheet business is often accompanied by greater risks than on-balance sheet business.

Credit risk refers to the risk that the object of the off-balance-sheet business service will default and the creditor will suffer the loss. A variety of off-balance-sheet business credit risk exists in varying degrees, such as guarantee business, the customer is guaranteed for some reason bankruptcy, can not fulfill the contract obligations, guarantee banks will have to bear the liability.

Interest rate and exchange rate risk refer to the fluctuation of market interest rate and exchange rate, which leads to the risk of loss of business in off-balance sheet business. In derivative financial instruments such as swaps, options trading and forward rate agreements, banks are exposed to the risks of adverse changes in interest rates and exchange rates. Under the trend of financial liberalization, internationalization and securitization, the security threat of interest rate and exchange rate risk to bank income is increasing day by day. For example, during the loan commitment agreement, the borrower can obtain a loan at fixed interest rate or variable interest rate . But during this period, if the market interest rates rise, the bank's capital cost increases the loan agreement interest rate and the cost of capital between the spread becomes very small or negative, and the borrower is bound to the maximum interest rate in the interest The use of loans, banks bear greater losses.

Liquidity risk refers to the difficulty that the bank faces in the shortage of positions when the transferable financial instruments can not be sold at a near-market price and the contingent assets and contingent liabilities are converted into real assets and liabilities. In the asset securitization business, through the issuance of asset securitization, the bank intervenes the new capital, increases the liquidity of the assets, but also increases the liquidity risk. Because when the market volatility, investors, banks are thought to pass on the risk of selling securities, but to increase the liquidity risk. In addition, in the letter of credit business, the commercial bank industry faces the liquidity risk which the debtor defaults, the contingent liability becomes the realistic liability.

The risks of the off-balance sheet business directly threaten the safety, liquidity and profitability of the commercial banks. In other words, the success or failure of the commercial banks is whether they can correctly identify the risks, control the risks, To achieve profitability. On the other hand, with the scale of the bank's off-balance-sheet business expanding, it will have a greater impact on the effectiveness of the macro-financial policy implementation and the stability of the financial system, more easily lead to systemic financial risks. To the destructive than the table business risk is more serious. Therefore, the management of off-balance-sheet business risk has become an important part of the risk management of international commercial banks. Especially in recent years, a series of financial turbulences and crises in the international financial field have sounded the alarm to guard against and control the risks to commercial banks engaged in off-balance-sheet business.

National regulatory authorities and commercial banks are also aware of the various risks, to build an efficient banking regulatory system and internal control mechanism is to ensure the sound operation of commercial banks one of the most important means. In view of this, the Western commercial banks in accordance with the Basel Committee on Banking Supervision in September 
1997 promulgated the "core principles of effective banking supervision" to strengthen the risk of off-balance sheet business operations and supervision.

\section{Accounting Calculation of Off - balance Sheet Business of China 's Commercial Banks}

Over the past few decades, off-balance sheet business has grown rapidly, with an increasing proportion of revenue and net income. In the developed countries, off-balance-sheet revenues generally exceed $25 \%$ of total bank revenues and even more than $50 \%$ of large banks. Such as the Swiss bank's off-balance sheet business profits accounted for $60 \%-70 \%$ of its total profit; the United Kingdom Barclays Bank's off-balance sheet business profits can cover more than $70 \%$ of its total operating expenses; 1992 Bank of America off-balance sheet business total profit of nearly 40 / RTI \& gt; In China, off-balance sheet revenues accounted for 3\% of total revenue, $5 \%$ of ICBC, $8 \%$ of China Construction Bank and 17\% of Bank of China. The off-balance sheet income of commercial banks in China The proportion of total income less than $8 \%$.

Compared with the scale of off-balance-sheet business and the degree of emphasis on risk control and disclosure of off-balance-sheet business, the off-balance sheet business of China's commercial banks is relatively narrow and the business volume is small. In the initial stage, especially the thought of heavy asset-liability business, light-off-balance-of-business, heavy-table accounting and light-off business accounting, it affected the rapid development of off-balance sheet business. On the current situation, China's commercial banks off-balance-sheet business accounting system, but also can not achieve fast, complete and true business information outside the table, nor with international practice.

Foreign banks are generally understood on the off-balance sheet business, while commercial banks in China mainly understand the off-balance sheet business mainly from the narrow sense, specifically refers to the risk of financial services such as trade services, this part of the financial activities of China's commercial Banks in the off-balance sheet items in the focus of reflection and records of the matter, and the risk of relatively small entrusted loans and other business into the table for accounting, this accounting method is not with foreign banks.

In the financial enterprise accounting system and specific accounting standards, the off-balance sheet business is not clearly defined, but with the contents of its description, which makes the table business and intermediate business two concepts easily confused, resulting in off-balance sheet business Accounting boundaries are unknown, the statistical caliber varies, resulting in accounting information distortion and confusion. From the concept, the nature of the point of view, off-balance sheet business is occurring but not involved or has not yet involved in changes in capital changes, does not affect the balance sheet trial balance, not included in the balance sheet business. It is from the accounting point of view to understand, is the concept of business with the corresponding table.

While the intermediate business refers to the commercial bank through its own special service functions for the customer for payment and other commissioned matters such as labor services. According to China's national conditions and the actual operation of commercial banks, commercial banks in the middle of the existing business, either in the form of assets, liabilities within the table reflect, it can not form a commercial bank statement of assets, liabilities; both can form interest Income business, but also can be formed non-interest income business.

Some commercial banks will accept bills of exchange, letters of credit, letters of guarantee and other matters on the balance sheet settlement, there are some commercial banks will accept bills of exchange, letters of credit, letters of guarantee and other contingencies The balance sheet can not truly reflect the performance of the off-balance-sheet business of the various lines and make the accounting settlement results of the various banks lack comparability.

First of all, at present most of the table is still set to remain in the surgical table to reflect and control valuable documents and important blank voucher-based primary stage. Second, most of the state-owned commercial banks, except for the off-balance-sheet subjects of the Bank's contingent assets and contingent liabilities, are not unitized but mixed in other off-balance-sheet accounts. Third, the settlement, payment and other business income of the subjects set more general and single, most banks only set "fee income", "other operating income" and so on. This is incompatible with the 
development trend of off-balance-sheet business, especially in the areas where the economy is developing fast and the off-balance-sheet operations are more. As an important means in the accounting and management of bank accounting, Business development needs.

\section{Summary}

After the 1980s, the off-balance-sheet business of commercial banks quickly became the biggest profit-making point of commercial banks because of its less capital requirements and lucrative profits. As the research and application of off-balance-sheet business of foreign commercial banks is relatively early and relatively backward in China, this paper makes a comparative study and systematic analysis on the development of off-balance-sheet business of domestic and foreign commercial banks.

Domestic academic circles and financial circles have been unable to distinguish the concept of out-of-balance business and intermediate business. Based on the accurate description of the concept of off-balance-sheet business adopted by the Basel Committee, this paper explains the current situation of extensive use of financial business in China. The concept of intermediate business, after a comparative analysis to determine the use of "off-balance-sheet business," the rationality of the term, advocate the use of domestic norms, the international common concept of an "off-balance sheet business.

At the same time, this paper analyzes the present situation of off-balance-sheet business of domestic commercial banks, analyzes the gap between the disclosure and accounting treatment of off-balance-sheet business and the current practice of western countries, and puts forward effective accounting and Information disclosure, which is not only conducive to the bank's own internal control, more conducive to the central bank's commercial banks to monitor the off-balance sheet business.

\section{References}

[1] The correct distinction and accounting of the off-balance sheet business in the bank. Financial Accounting. 2004 (3) 9-11.

[2] Comparative Research on Commercial Banks' Off-balance-sheet Businesses. Rural Finance Research. 2003 (2) .30-33

[3] "Journal of Central University of Finance and Economics" 2001 年 10 期 "Journal of Central University of Finance and Economics" 2001-01 Add to Favorite Get Latest Update On the Commercial Banks'

[4] The Risk and Management of China 's Commercial Banks' Off - Balance Sheet Industry.

[5] A Brief Analysis on the Disclosure of Off-balance-sheet Business of Commercial Banks. Market Weekly. Finance Forum .2003 (8): 21-22.

[6] Zhao Guangli, Zhaohuan Zhong achieve Oracle database security management technologies based on Computer Engineering and Applications, (2012): 37-41.

[7] Zhu Jingwei. JAVA / CORBA distributed database access technology-based research and Xi'an University of Electronic Science and Technology, (2011).

[8] Du Jiangjie. XML and its application in Intranet Information System. Xi'an University of Technology, (2009), 6.47-49.

[9] Wang Hui, Zhang Xiaohui, M. Tom Myequery_result, Alexander Nakhimovsky Java XML Programming Guide Beijing: Electronic Industry Press, (2011): 198-206. 